\title{
Japanese centre set to boost efforts in brain research
}

Wako City, Japan. The Institute of Physical and Chemical Research (RIKEN) in Wako City in the northwest suburbs of Tokyo is set to become one of the most powerful centres for brain research in Japan.

In October the brain research section of the institute's highly successful Frontier Research Programme will double in size through the opening of three new laboratories, and further expansion is already being planned.

RIKEN's Frontier Research Programme has become widely known since it was established in 1986, partly because its research projects are closely monitored by external reviewers, and partly because of deliberate efforts to draw on the talents of foreign as well as Japanese scientists. Both are unusual for Japan.

The programme started with two broad research fields, biohomeostasis (which includes research on areas such as ageing and intestinal flora) and 'frontier materials', which initially focused on quantum devices, nonlinear optics and bioelectronic devices. Research on brain mechanisms of mind and behaviour was added in 1988 .

In addition, two Frontier research centres have been opened on other sites. One in Sendai, north of Tokyo, opened in 1990 and focuses on photodynamics research. The other in Nagoya, southwest of Tokyo, opened last year and specializes in research on biomimetic control: it aims at combining RIKEN's expertise in brain and materials research and in the development of sensor technology with robotics research and studies of the molecular biology of the brain.

Three new laboratories for research on brain information processing will be added in October at RIKEN's Wako City campus. These are the Laboratory for Neural Modeling, the Laboratory for Information
Representation and the Laboratory for Artificial Brain Systems.

RIKEN officials say they hope to win approval for several more brain research laboratories in next year's budget. A decision on whether to apply to the Ministry of Finance for funding will be made by the Science and Technology Agency, which provides most of RIKEN's budget, at the end of August.

Brain researchers are "scattered in many small groups" in universities around Japan, says Katsutoshi Yasufuku, an administrator of the Frontier programme. He says RIKEN means to bring together a large and powerful group at a time when there are several leading researchers in neuroscience in Japan.

In cooperation with the new brain research groups, the institute also hopes to develop brain scanning technology, such as magnetic resonance imaging, positron emission tomography, and scanners for detecting minute magnetic fields in the brain, as well as techniques for artificially growing and keeping brain slices.

Neuroscientists at RIKEN are led by Masao Ito, one of Japan's leading brain researchers and also the director-general of the whole Wako Frontier programme. They are so confident of the quality of their research that they are already planning to request a second external review of the brain research laboratories during their first phase of operation.

External reviews take place at two levels. The Wako, Sendai and Nagoya centres each have an advisory council made up of leading Japanese and foreign scientists. The councils, whose members change every three years, meet once or twice a year to review the research and suggest future directions for the programme at each site as a whole.

David Swinbanks

\section{Japan edges cautiously towards gene therapy}

Tokyo. Japan took another cautious step towards its first application of gene therapy last week when a medical ethics committee at Hokkaido University in Japan's northernmost island gave "emergency" approval for the genetic treatment of enzyme deficiency in a 3-year-old boy.

The proposed treatment is for adenosine deaminase (ADA) deficiency, which can lead to a breakdown in the immune system, and the approval has been requested by Yukio Sakiyama in the university's department of paediatrics.

The proposal was submitted to the university committee last November. But it was not approved until last week because of the tardiness of the Ministry of Education, Science and Culture, which has administrative jurisdiction over all Japan's universities, in introducing a system for screening such experiments.

More bureaucracy lies ahead. Both the Ministry of Health and Welfare and the education ministry have set up committees to screen such experiments, and approval is required from both - even though some scientists belong to both committees (see Nature 369, 5; 1994). Sakiyama says he hopes to submit "basically identical" proposals simultaneously to the two committees in the near future.

\section{French ministers face public trial in HIV blood affair}

Paris. The French dispute over responsibility for the distribution to haemophiliacs of blood contaminated with human immunodeficiency virus (HIV) in the mid-1980s erupted again last week with a decision to permit charges to be heard against three former socialist ministers who were in office at the time.

The decision results from a reform of the High Court of Justice last year which allows any individual - and not just parliament to bring charges against ministers, in this case Laurent Fabius, the then prime minister, Georgina Dufoix, then minister of social affairs, and Edmond Hervé, then deputy health minister (see Nature 364, 269; 1993).

The Court of Justice of the Republic last week accepted 11 civil suits against the three politicians. Indeed the reform was itself prompted by the failure of repeated attempts to try the three politicians.

These will probably now face criminal charges of deliberately administering substances dangerous to health. If convicted they could face prison sentences of five to ten years. The charges would cover the period between March 1985 — the date when the government is acknowledged to have been informed that unheated bloodclotting factors were contaminated with HIV - and October 1985, when the French National Blood Transfusion Service (CNTS) stopped their distribution.

The prospect of charges against the three politicians is likely to give renewed prominence to the affair, particularly as Fabius is a potential candidate in next year's presidential election.

Attention will focus on the role played by the ministers' scientific advisers - against whom separate charges are pending - in the delays in introducing both heat-inactivated blood products and routine screening of donated blood for HIV (see Nature 367, 304 \& 673; 1994).

In a separate development, it was announced last week that Michel Garretta, former director-general of the CNTS, is to be retried on the criminal charge of 'poisoning'. Garretta had already been sentenced to four years' imprisonment in 1992 on the misdemeanour of "deception over the quality of products sold".

The decision to press further charges against Garretta follows a ruling last month by the Paris Supreme Court of Appeals.

Garretta's lawyers have already said that they will fight the new decision in the European Court of Human Rights, pointing out that the European Convention on Human Rights states that no one can be tried on different charges for the same act.

Declan Butler 